\title{
Visualizing Memory Scapes: A Spatio- Affective Study of Select War Memorials of Jammu and Kashmir
}

\author{
Ritika Pathania ${ }^{1}$ and Raj Thakur ${ }^{2}$ \\ ${ }^{1} P h D$. Department of English, Central University of Jammu, JEK, India. Address: H.no. 218- \\ E, Sainik Colony, Jammu-18oo11, JEKK, India. Email: ritikagfeb@gmail.com. Orcid id- \\ https://orcid.org/oooo-ooo1-56o8-7588 \\ ${ }^{2}$ PhD. Assistant Professor, Department of English, Central University of Jammu. Bagla \\ (Rahya Suchani) Distt. Samba, JEKK, India. Email: thakurraj.13@gmail.com. Orcid id- \\ https://orcid.org/oooo-0002-6962-3658
}

\begin{abstract}
The paper through iconographic and spatial dynamics, critically engages with the performative aspect of the select war memorial sites in the erstwhile state of Jammu and Kashmir. While the interdisciplinary study of war memorials in relation to memory and commemorative politics have been studied, its materialistic aesthetics informed through spatial and affective contours remains a burgeoning field of enquiry if not an unexampled one. The study is premised on the photographic field work of the sites envisioned through the cultural geography of war memorials. In approaching war memorial sites as a landscape of memory, we take the position that memory is simultaneously a material and immaterial phenomenon and these cannot be detached from affective and visceral human bonds and their roles in (re-)formulations in space and place. The materialistic aesthetics of memory- memorial continuum are ideated through spatial and affective contours, which, in turn, inform the predominant and everyday experience of grief and bereavement, both imagined and lived. The study dominantly attests its claims through Foucault's concept of 'heterotopia' in relation to commemorative sites. The heterotopic tensions of multiple experiences and belongings are unpacked through both tangible and affective domains ranging from dominant public commemorative sites to parks and shopping complexes.
\end{abstract}

Keywords: war memorials, memory, spatiality, affect, Jammu and Kashmir

\section{Introduction}

The memory making sites- War memorials and monuments play a fundamental role in shaping and moulding the images of events that demand remembrance. The act of remembrance becomes significant for not just an individual or nation but also the way that very history and experiences are perceived in time. There are different modes of remembering the past and the choice of media and forms have an effect on the kind of memory that is created. The visual representation of war through the study of commemorative war memorial becomes a crucial component in shaping the politics of war memory. War as a 'performative field' allows us to understand the ways in which performance can be used to secure and maintain power across social strata. Performance in a militarized culture heavily draws upon the spatial metaphor. Mieke Pearson and Michael Shanks in Theatre/Archaeology write that performances are "inseparable from their sites, the only context

(C) AesthetixMS 2021. This Open Access article is published under a Creative Commons Attribution Non-Commercial 4.0 International License (http://creativecommons.org/licenses/by-nc/4.o/), which permits non-commercial re-use, distribution, and reproduction in any medium, provided the original work is properly cited. For citation use the DOI. For commercial re-use, please contact editor@rupkatha.com. 
within which they are intelligible" (2001, p.23). In this sense, war memorials in such sites of performance unpack the ways in which meaning has been made in the given socio-political environment. To deliberate upon the visual vis- a -vis performative aspect of war, Judith Butler, an American cultural critic, in Frames of War (2010), points out that visual and discursive field are part of waging and recruiting support for war. Butler asks us to reconsider what is meant by the notion of the "material conditions of war" (2010, p. 26), which are often understood as guns and bombs, but might also include, for example, the camera. These material instruments of war form a symbiotic relationship between the photographs and the conduct of modern war.

The erstwhile state of Jammu and Kashmir has witnessed various wars and is a home to great number of commemoration sites. The contested territory of Jammu and Kashmir gained its importance after the British withdrawal from South Asia in 1947. The state that formed part of a complex political buffer zone interposed by the British has continued to remain a politico- military hotspot to the present day. Jammu and Kashmir's culture and identity are historically linked to the country's military and the wars it has participated in. The military history of Jammu and Kashmir starting from the First Kashmir War of 1947-48 followed by the Sino-Indian Conflict of 1962, the Second Kashmir War of 1965, the 1971 War, to the Siachen conflict of 1984 and to the Kargil Conflict of 1999 represents the contours of nationalistic discourse which are embedded in its militarymemorial continuum.

The visual economy of memory scapes invites iconographic study of the 'Dhruva War Memorial' in Udhampur, 'Kargil War Memorial' at Drass and various other memorial sites in Jammu. The location of these memorials and monuments has imparted great fuel to this paper as 'space' has been a dominant narrative in visual culture. Concept of space, as Michael de Certeau contends, "takes into consideration vectors of direction, velocities, and time variables" (2011, p.117). It is "composed of intersections of mobile elements" (2011, p. 117). A war memorial site can also be understood as a space where we can consider the relationships and interactions-for example, between visitors and memorial exhibit that occur in the place. Spaces are, according to de Certeau, "practised places" (2011, p.117), locations in which human practices take place. In this sense, the space of Kargil war memorial in Drass where the actual Kargil war was fought works well as a 'performative metaphor' for the public to 'feel' the actual site of conflict. The space that has witnessed the bloodshed and fury of war act as a catalyst of regenerating the dead memories of lost ones.

Since time immemorial the ritual of the commemoration of war dead has been the tradition of 'social cohesion' of memory. Polly Low while contextualising the Greek commemorative rituals describes:

Archaeological evidence from fifth century Greece demonstrates social commemoration of the soldier as hero. The overriding message in the inscriptions being that the men had died for the cause of civic identity; what Low describes as an early example of the nation-state concept. (As cited in Abousnnouga, 2012, p.46-47)

So, through habitual ritual, generation after generation has learned that the sacrifice of life for a collective cause will be commemorated. The way society commemorates war has been traditionally explored by cultural critics like Hobsbawm \& Ranger (1983), Anderson (1983) and Winter (1999), each approaching the topic from their own theoretical perspectives and traditions. The literature on Vietnam veteran war memorial erected in Washington, D.C. USA centres on the memorial's intrinsic features, while some attend to viewers' behaviour towards the monument. In "The 
Vietnam Veterans Memorial: Commemorating a Difficult Past," Professors Robin Wagner-Pacifici and Barry Schwartz assert that "to list the names of every fallen soldier, with no symbolic reference to the cause or country for which they died, immediately highlights the individual" (1991, p. 42). However, there is a need to investigate war memorial and its commemoration as a cultural practice both through the materialistic aesthetics of dominant and everyday scapes.

The study of material culture revitalizes investigations into the physical and symbolic worlds that war has created, and that define us as subjects through memory, imagination, and technology. War photographs, films, war memorials, war souvenirs and museums are all warrelated manifestations that create and perpetuate different engagements with conflict and its aftermath. The question of how objects convey memory turns on how we consider objects to communicate meaning. Nicholas J. Saunders in "Culture, Conflict and Materiality" emphasizes on the material dimension of a modern war where he notes:

Conceiving materiality [...] enables us to construct a biography of the object [...] - to explore its 'social life' through changing values and attitudes attached to it over time [...]. Many objects survive as expressions of 'war beyond conflict', revitalising meanings and creating new engagements between people and things. (2005, p.78)

\section{Methodology}

The methodology followed in this study is based upon the semiotic study of war memorials and monuments through spatial and affective contours. It is premised on the field work consisting of photographs and other visual evidences of the select war memorials. The iconographic study primarily relies on W.J.T. Mitchell's foundational study of iconography. Visual cultural studies are closely identified with its parent field of cultural studies in its approach to images through 'the circuit of culture' model (du Gay et al., 1997, p. 3). Since cultural studies is concerned with 'how culture is produced, enacted and consumed' (2000, p.61) it is inevitable that scholars working in this area would engage with the visual. The approach attends to "the many moments within the cycle of production, circulation and consumption of the image through which meanings accumulate, slip and shift" (Lister and Wells, 2000, p. 90).

Particularly relevant here is W.J.T Mitchell's dialectics of images to explore how objects become metaphor for the self and visually determine their representation:

Images are not just a particular kind of sign, but something like an actor on the historical stage, a presence or character endowed with legendary status, a history that parallels and participates in the stories we tell ourselves about our own evolution from creatures "made in the image" of a creator to creatures who make themselves and their world in their own image. (2005, p. 3)

Paralleling the concern in "Culture, Conflict and Materiality", Nicholas Saunders aptly remarked, "Battlefield landscapes, memorials, cemeteries, reconstructed buildings and towns, museums and memorabilia are all material representations of memory, spirituality, ethnicity, politics and emotion that link the living with the dead in a complex interplay of past and present" (2005, p. 78). The affective dimensions of the memorials play a significant role in augmenting the memory scapes. Pinning down on the emotive force of material culture, Andrew Jones in Memory and Material Culture pronounces how "the emotive effect of material culture is bound up with an 
objects sensory impact", wherein, "specific social performances, produces emotion" (2007, p. 65). This suggests how visual images 'invoke sensory' effect or rather produce 'affective economies ${ }^{\text {'i }}$ by reproducing an event of past in its 'spectacular' form. Sara Ahmed in "Affective Economies" talks about the 'economic model of emotions' and says, "while emotions do not positively reside in a subject or figure, they still work to bind subjects together. Indeed, to put it more strongly, the non residence of emotions is what makes them "binding"' (2004c, p.119). Her take on affect and collective identities, which sees emotions as things that 'circulate' in the collective, rather than as things that are individually and internally carried (Ahmed 2004a, 2004b, 2004c). Though not directly addressing collective memory, her exploration of how emotions 'align' individuals with the nation through intense attachment, and the crucial role of what she calls 'sticky objects of emotion' in this, offers insights into the cultural process of collective memory construction.

By examining the way Dhruva and Kargil memorial's war memory takes shape in the circulation of emotion and in the exchange and interaction between subject and exhibits, the study explores its latent memory- affect ascriptions. War memorial's memory is not frozen in its exhibits but forms in the in-between space of its exhibits and visitors, via the affective truth that is generated in visitors' engagement with the exhibits. The study focuses on what Erika Doss remarks as, "'the affective possibilities' of public feelings, and a consideration of how public commemoration can be emotionally productive" (2010, p.59-60). To highlight how emotions are culturally scripted, Pramod K. Nayar states:

[...] events and individuals are positioned and represented in certain ways so that an 'emotional dominant' is built around it, and which is then likely to influence our responses to those events and individuals. This means, emotions and emotional responses are situated in a social and cultural context, even if they 'emerge' from deep inside us. (2011, p. 11)

\section{Spatial trope}

To grasp the memory making potential of spaces, we need to observe the social actions and the placement of material objects which occur within them. Robert Tally advocates the significance of "space to have a more equal footing with time" (2013, p. 3) in critical theory, which until the Second World War had been dominated by "discourses of time, history and teleological development" (2013, p. 3). Spaces of death, and their significance in memory making, have been transformed across historical time in both their material form and their metaphorical potential.

What dominantly informs the study here is the residue of memory spaces examined through Foucault's spatial dynamics of power and discourse embedded in the notion of 'heterotopia'. He first used the term in the preface to The Order of Things (1966) to describe other, different and entirely unimaginable space. They are spaces that evoke, and hold together, discontinuous times and spaces. The study of memory spaces brings a new focus on the zoning and ordering of memorial spaces and therefore of different memorial activities, groups and agendas. The varied spaces of memorial practice allow us to explore the ways in which different arenas are shaped by particular agencies and how they engage, self consciously and unselfconsciously, with notions of memory and place.

Elisée Reclus, an anarchist geographer, while theorizing on the materiality of space through the lens of memory opines, "Geography is nothing but history in space" (as cited in Wilson, 2016, p. 235). Memory has become one of the categories which scholars use as a lynchpin for their worldview often to support arguments concerning the breaks between pre-modern, modern and postmodern worlds. The concept of 'place' and the organisation of space too has become an organising concept, 
a catalyst to encourage the understanding of the past, present and future. Michael Foucault emphasized the relationship of power to both space and memory. "Space is fundamental in any exercise of power" (as cited in Crampton et.al., 2007, p. 45) and "if one control's people's memory, one controls their dynamism" (as cited in Osiel, 1997, p.210).Jo-anne Mary Morgan in Sites of Memory: Memorialisation in the Landscape points out:

In studying the cultural landscape of memorials and monuments, one in fact studies the landscape of the war dead, as the act of commemoration in celebrating and preserving the memory of a person or event generally implies that the person is dead and that the event is in the past. However, it is also a landscape of collective values, reproduced over time, sometimes retaining contemporary meaning, sometimes not. This is why Curl is right when he said "to be concerned with death and with its celebration is not 'morbid'. (2001, p. 4)

\section{Spatio- Affective Case Study}

The Kargil war memorial at Drass becomes a charged site of affective mediation, where people are called upon to reflect and react to the suffering rather than to merely imbibe historical information. The audience in such exhibits internalizes the cultural codes of emotional state of grief. "The Hut of Remembrance" (Picture 1) in Manoj Pandey Gallery at Kargil war Memorial is one such narrative which serves to represent the politics of suffering through the text of images. The dominant iconography of the hut traces how war memorials perform in the public mediation of affect through their ritualized acts.

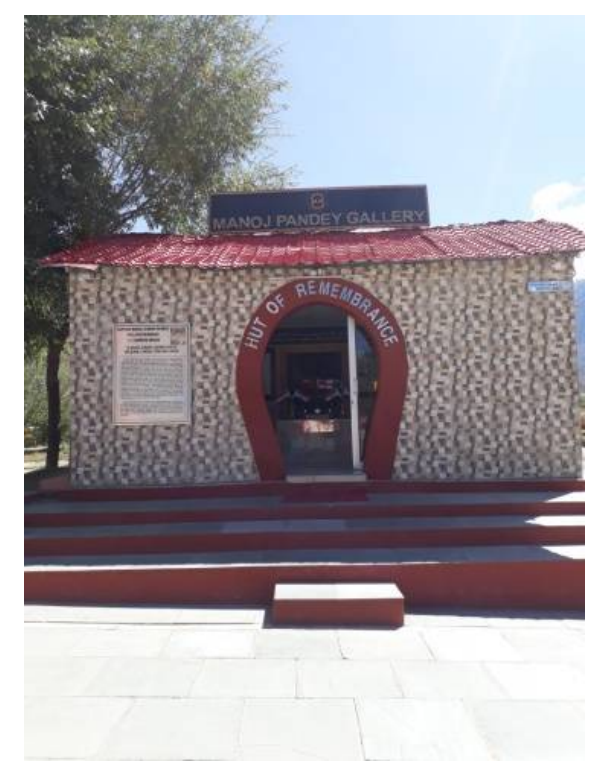

Picture 1, Manoj Pandey Gallery at Kargil war memorial, Drass.

On 26 July 2009, the Manoj Pandey war memorial gallery was inaugurated in the Kargil war memorial, marking the tenth anniversary of Kargil war. Captain Manoj Kumar Pandey was awarded Param Vir Chakra (gallantry award) posthumously. His brother, Manmohan Pandey who was accompanied by his mother said: "He is my hero as well as the nation's hero. I had come here to pray at the place where my brother sacrificed his life. This place is a temple for me" ("Kargil martyrs remembered"). Another family member of Kargil war victim, NeiselieKenguriise, father of Captain Neikezhakuo Kenguriise who sacrificed his life when he led a platoon to recapture Tololing said, "It was a dream for us to visit the holy place and pray for our son" ("Kargil martyrs remembered"). The 
cultural codes of these emotionally meaningful discourses influence and circumscribe the memory of Kargil war. They highlight the relevance of suffering and its cultural significance in nation building. As Nayar points out; "Collective mourning and collective memorialisation is a public acknowledgement of suffering. [...] these are rituals of collective bereavement" (2011, p.111). The "Hut of Remembrance" at Kargil war memorial stresses on the relation between affect and institutional mediation as pointed out by William Mazzarella, specifically with regard to "public efficacy" (2009, p.298), wherein such exhibits win the admiration of people who align the fallen dead with heroic virtues.This takes us to Brian Massumi's idea that affect is not 'presocialii'. There is a reflux back from conscious experience to affect, which is registered, however, as affect, such that "past action and contexts are conserved and repeated"(Clough, 2007, p. 4).

An important aspect of the power of places, an aspect directly connected to pictorial and textual representations, is conveyed by the notion of landscape. For W. J. T. Mitchell, landscape is already encoded with cultural values and meanings and is "best understood as a medium of cultural expression" (1994, p. 14). Landscape is hence, both a human and a natural construct.

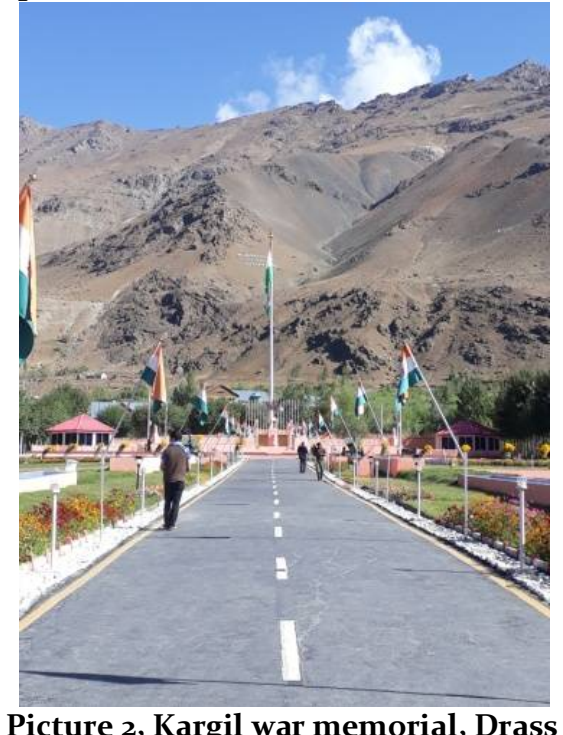

Located in Drass, in the foothills of the Tololing Hill, Kargil war memorial shown in Picture 2 is a war memorial built by the Indian Army. The memorial commemorates the soldiers and officers of the Indian Army who were martyred during the 1999 conflict between India and Pakistan. The memorial is located about five kilometers from the city centre across the Tiger Hill. It is located on the Srinagar- Leh National Highway 1D. Surrounded by majestic peaks, the Tololing peak overshadows the visitors making one realize how close the battle was fought to the city. The hovering of clouds over the rugged peaks gives a spectacular imagery of the landscape. The path from the entrance gate to the memorial wall is called the Vijay Path or Victory Path. The path is resplendent with the Indian Tricolor adorning either sides. With the war memorial right below the Tololing Hill, the visitor gazes at the grandiose nature of the hill. The sanctum- sanctorum of the war memorial is the eternal flame of Amar Jawan (Immortal Soldier) which is kept lit $24 \times 7$. The eternal flame provides vigil to the inverted rifle with helmet, depicting the unknown soldier. Behind the Amar Jawan is the 'Wall of Heroes'. The wall made of bronze metal has names of the soldiers who sacrificed their lives while fighting in those peaks that surround the memorial. The reflection of battle peaks on the metallic surface of the wall with yellow marigold 

Kashmir

flowers in the vicinity at once gives the imagery of war ridden landscape that witnessed intense fury of war in the past but now is a calm resting place to the fallen dead.

Ladakh's strategic dimension is one area of study which brings forth the effects of war in the contemporary visual society. Ladakh becomes the gateway to visible, visual and iconic spatial entity. The memorial site invokes Ladakh's geo-political imaginary as an affected and contested site marking a shift from its pre Kargil 1999 War image as a remote, rustic land that lied on the fringe of modernity. The role of Ladakh as a factory of national imaginary can no longer be treated as peripheral. Ladakh captures the war spectacle and functions to create a strategically dominant position. Kargil war memorial built in such a landscape offers multitudinal affective mileage to its politics of representation.

\section{The Spatiality of Grief and Bereavement}

The war memorial landscape plays a crucial role in mapping grief and bereavement in its physical as well as the embodied- psychological spaces of body and mind. Bereavement, grief and mourning represent different aspects of loss, the experience of sorrow, and associated processes and rituals. As Bondi et al. (2005) have argued "embodied emotions are intricately connected to specific sites and contexts" (p.5). Furthermore, "bereavement, grief and mourning are experienced within space and can be both triggered and ameliorated in relation to particular places at particular times" (as cited in Maddrell, 2016, p. 169). In the Production of Space (1994) Lefebvre describes space as organic, fluid, alive and dynamic. He invites one to "capture in thought the actual process of [the] production of space" (Merrifield, 2000, p. 173). Understanding the impact of death and bereavement on people's understanding and relation to place is part of that 'production' process.

Echoing the spatial poetics, Avril Maddrell remarks, "The landscape is a palimpsest not only of life, but also of the social relations and practices associated with death and remembrance" (2016, p.170).

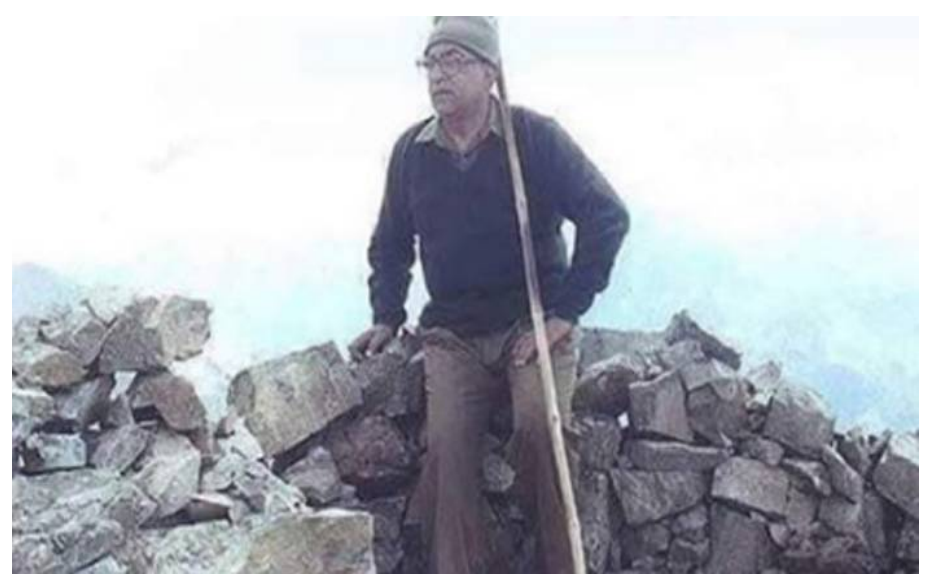

Picture 3, An India TV post of Colonel Vijendra Thappar (Retired) father of Captain Vijayant Thappar, dated August 11, 2016

The above Picture 3 from an India TV post mentioned, “Goosebumps! Kargil War Hero Captain Vijayant Thapar's father climbs $16000 \mathrm{ft}$ to visit the place where his son achieved martyrdom” (2016).

The post stated that Colonel Vijendra Thappar (Retired) father of Kargil war hero captain Vijayant Thappar fulfilled his 17 year old emotional wish to visit the place where his valiant son sacrificed his life fighting Pakistan backed infiltrators. The seventy four year old Thappar climbed 
16,0oo feet to fulfil his last wish and sat on the mountain rock where his son died fighting for the country. Triggering the moment, Karen Till states, “[...] places are never merely backdrops for action or containers for the past. They are fluid mosaics and moments of memory, matter, metaphor, scene, and experience which create and mediate social spaces and temporalities" (2005, p. 8). Thus, particular spaces become emotion-laden places. The sites of war memory become symbolic spaces invested with the meaning of grief and bereavement for next of the kin of the fallen dead. Death and bereavement produce new and shifting emotional-affective geographies here.

Pinning down on the idea of grief, the war memorial landscape provides space for human interaction. In this regard, the Kargil and Dhruva war memorial is a case of a "space of absence", defined by Richard Edin as a "void in which we have the simultaneous experience of both the absence and the presence of the dead" (as cited in Ochsner, 1997, p. 1). The definition of absence is "the state of being away, not present" (Chambers, 1990, p. 5) whilst presence is defined not only as "the fact or state of being present" but also "something felt or imagined to be present" (Chambers, 1990, p. 5). There is an immediate dichotomy between these two statements. The definition of presence as "something felt or imagined to be present" highlights the absence of the physical presence of the "something". This brings in a condition of perception or an affect that something is missing. The awareness of something, or indeed, someone, being physically present, where the mental, that is, the human experience, intersects with the physical, is significant. It points to a liminal space where the limen, the threshold, is that of human experience, beyond which is absence. Closely linked to the idea of nothing, Francis McKee writes "Often 'nothing' is no more than something imperceptible to our senses or beyond the reach of our technologies" (as cited in Wright, 2013, p. 9). The link between the sensation of presence and the sensation of absence can be reversed creating an absence that can be seen as possibility as well as lack.

\section{Non- Territorial Memory Scapes and Heterotopia}

Michael Foucault's "Of Other Spaces" states: "Our epoch is one in which space takes for us the form of relations among sites" (1984, p.3). He is particularly interested in those sites which "have the curious property of being in relation with all the other sites, but in such a way as to suspect, neutralize, or invert the set of relations that they happen to designate, mirror, or reflect" (Foucault, 1984, p. 3). Musing over these interstitial spaces, Mirzoeff contends, that there are two kinds of such spaces, the utopia and the heterotopia. Utopias, in common with heterotopias, "have a general relation of direct or inverted analogy with other spaces in that they present society itself in a perfected form, or else society turned upside down" (Mirzoeff, 2002, p.239) There is, however, an important difference between them: heterotopias are "real spaces", while utopias are "unreal spaces" (Mirzoeff, 2002, p.239). Heterotopias, that exist in every culture, every civilization are "something like counter-sites, a kind of effectively enacted utopia in which the real sites, all the other real sites that can be found within culture, are simultaneously represented, contested, and inverted" (Mirzoeff, 2002, p.239). Memorials have a "function in relation to all other space" in several ways (Mirzoeff, 2002, p.243). For Foucault, inbetween the utopia and the heterotopia lies the mirror, which is both physically real and unreal: "In the mirror, I see myself there where I am not, in an unreal virtual space that opens up behind the surface ... But it is also a heterotopia in so far as the mirror does exist in reality, where it exerts a kind of counteraction on the position I occupy" (Mirzoeff, 2002, p.183). Foucault's claim seems applicable to the utopic version of our culture that is offered by the memorial sites. In his discussion of monumentality, Henri Lefebvre refers to the mirroring capabilities of the monument and states, "Monumental space offered each member of a society an image of that membership, an image of his or her social visage. It thus, constituted a collective mirror more faithful than any personal one" (1991, p.220). The mirror as a 
function of the heterotopic space can be applied to war memorials in that they project civic ideals about nationalism, citizenship and sacrifice. Foucault goes on to outline six principles of heterotopia ${ }^{\text {iii }}$ that could constitute the study of heterotopias or what he calls "heterotopolgy- a sort of simultaneously mythic and real contestation of the space in which we live"(Mirzoeff, 2002, p.240).

The non- territorial memory spaces like roadside monuments, parks, shopping centres and other zones which escape the everyday public gaze act as heterotopic sites of memory. These take varied forms in different cultures and can, as Foucault's second principle notes, "change function over time" (Mirzoeff, 2002, p.241). Roadside memorials are sites that are always unfinished. Unlike, a gravestone, sculpture or monument, they continually change, they are not static spaces and so their meaning, role and function change over time. They signal the suddenness and immediacy of the death, an explosion of emotion in otherwise drab and functional spaces.

The third principle of heterotopia describes how spaces can take on multiple meanings and associations. Foucault describes the heterotopia as "capable of juxtaposing in a single real place several spaces, several sites which are themselves incompatible" (Mirzoeff, 2002, p.241). As Eleanor Bavidge points out:

Church graveyards are no longer the only places where one can stage the relationship between the living and the dead. Local parks and road sides now provide a counter space or an additional space to locate the relationship between the two, thus creating a sacred site in a secular spot. (2009, p. 115)

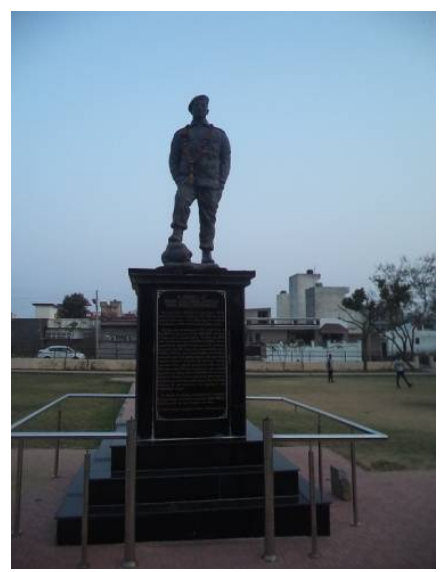

Picture 4, Major Ajay Singh Jasrotia's statue at Sainik Colony, Jammu

A monument built in the memory of war deceased Major. Ajay Singh Jasrotia (See picture 4) in a park near to his house in Jammu shows the commingling of private and public spaces, where secular space mixes with the sacred. In the third principle, Foucault makes reference to the theatre and to the cinema as examples of heterotopia:

Thus it is that the theater brings onto the rectangle of the stage, one after the other, a whole series of places that are foreign to one another; thus it is that the cinema is a very odd rectangular room, at the end of which, on a two-dimensional screen, one sees the projection of a three-dimensional space. (Mirzoeff, 2002, p.241) 
The picture 4 follows as a movie by basing this on the third principle. It locates this rectangular space of the monument in the dimension of another rectangular playground. A playground here meant for the young lads to play signify youth in the springtime of their life, on the contrary, the statue of a young man who was killed in war symbolizes an act of self sacrifice for the country. This highlights the space that has in it a different location which is contradictory in meaning.

Another example of Foucault's third principle can be seen in a monument at Triveni Shopping Site at Satwari cantonment in Jammu that depicts how memorials also fashion against the backdrop of shopping mall (See picture 5).

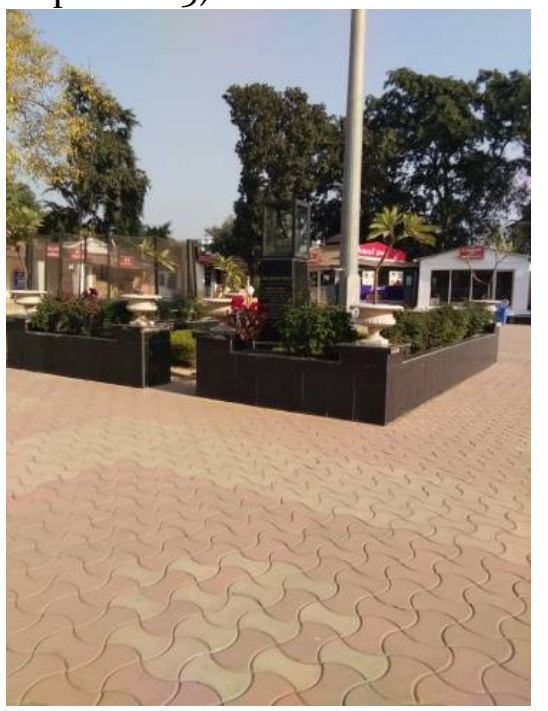

Picture 5, Bust of Lieutenant Triveni Singh at Triveni shopping complex in Satwari Cantonment, Jammu

The rectangular space of a soldier's bust inside a shopping complex with similar dimensions juxtaposes the different spaces with contradictory meanings into one. The politics of space and place is thus a complex matter that foregrounds Guy Debord's idea of 'spectacle'. In his founding book, The Society of Spectacle, he states that spectacle, "is not a collection of images; rather, it is a social relationship between people that is mediated by images" (2006, p. 2).Tracking the sociality of everyday through such sites, Mohammad Reza contends, "A memorial space not only transfers the memory of events to the next generation but also is a place for social interactions" (Reza et al., 2016, p. 59).

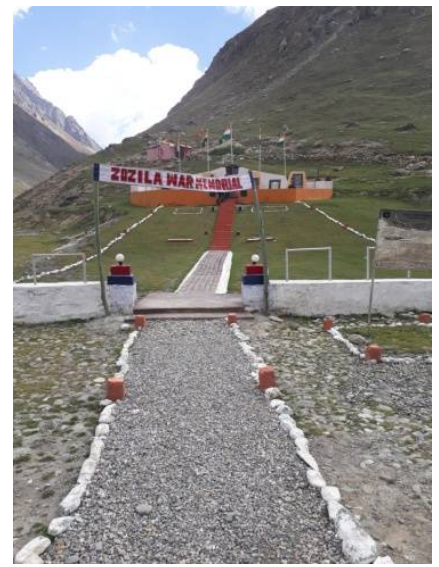

Picture 6, Zojila war memorial at Gumri, on the way to Kargil 

Kashmir

Zojila war memorial (Picture 6) on the way to Drass, is one such memorial that underpins Foucaults claim of "desanctification of space" (1984, p.2). Eleanor Bavidge in "Heterotopias of Memory" opines, "The assumed desacralization and deritualization of western societies is challenged by the presence of roadside memorials." (2009, p.115) Although, Foucault discusses how Galileos work contributed towards the desanctification of space, he claims that space in contrast to time is not desanctified yet. The still prevailing fissions between "private and public, family and social space, cultural and useful spaces and between spaces for work and leisure reveal the hidden presence of the sacred" (Mirzoeff, 1998 p. 2)

Roadside memorials are an attempt to set up a reserved, special and sacred place within social space and so create a site of multiple meaning. Sites of death embody aspects of the heterotopia by transforming ordinary spaces. Hallam and Hockey recognise the heterotopic nature of memory spaces claiming that "death has the power to create heterotopias, that is, the layering of meaning at a single material site" (2001, p.84). Hallam and Hockey see how layered meaning is produced at a site at which "the abject and the ordinary are brought into uneasy conjunction" (2001, p.83). The abjection at these sites as Hallam and Hockey claim is then brought under control or erased though ritual acts, like placing flowers, which purify the site (2001, p.83).

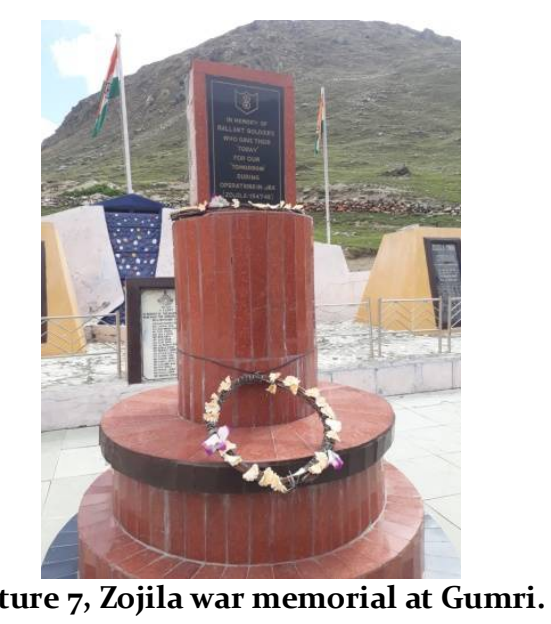

The transience of flowers and the solidity and permanence of stone as seen in Picture 7 at Zojila war memorial, have made them key to rituals of remembrance. The symbolic fragility of flowers at roadside memorials emphasizes the fragility of life. Their naturalness is in direct contrast to the artificiality of the concrete environments in which they are placed. These things are meant to bind the living and the dead, and "preserve a material presence in the face of an embodied absence" (2001, p.18).

War memorial sites as spaces of memory, like heterotopias, are always linked to different "slices of time" (Mirzoeff, 2002, p.242). They not only conjure up the time they commemorate but they also articulate the memorial's moment in which they were needed, conceived and erected (see Picture 8 and 9). The inscription on the headstone in Picture 8- "In Memory of RFN Tam Bahadur of $1 / 5$ GR who made the supreme sacrifice while serving the nation on 23 Nov 48 " at Kargil war cemetery offers its visitors the different slices of time from 1948 to present. 


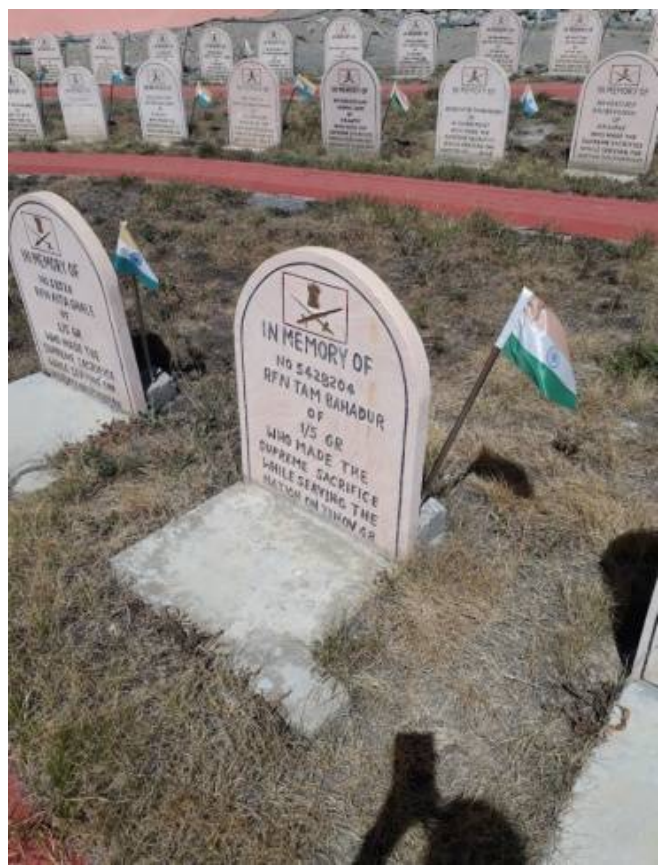

Picture 8, Kargil war cemetery at Drass

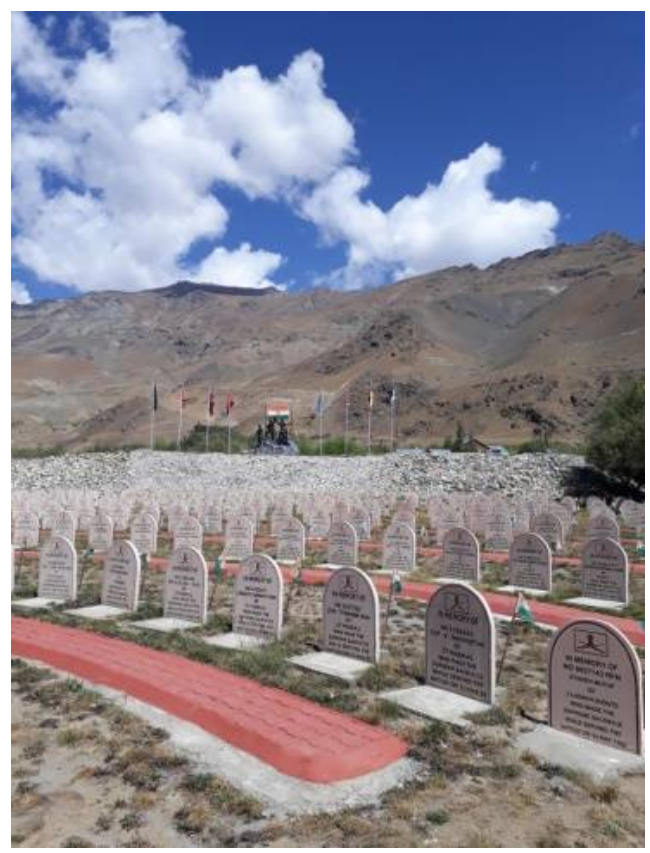

Picture 9, Kargil war cemetery at Drass

Another Foucauldian principle which is evident at war memorial site is that "the heterotopia is capable of juxtaposing in a single real place several spaces, several sites that are in themselves incompatible" (Mirzoeff, 2002, p.241). 


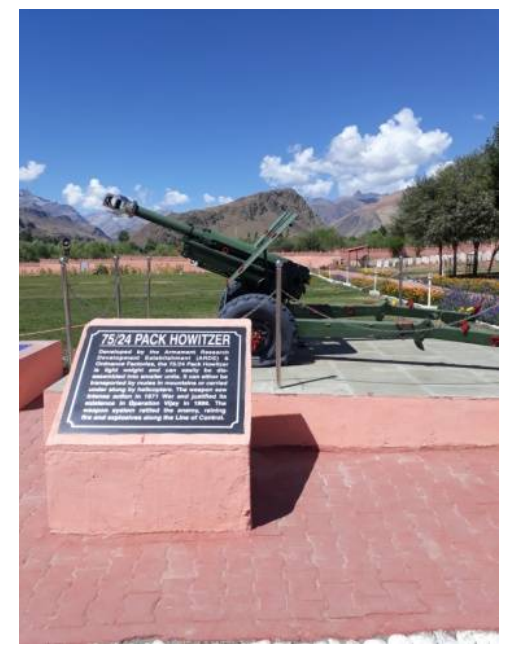

Picture 10, War weaponry displayed at Kargil war memorial

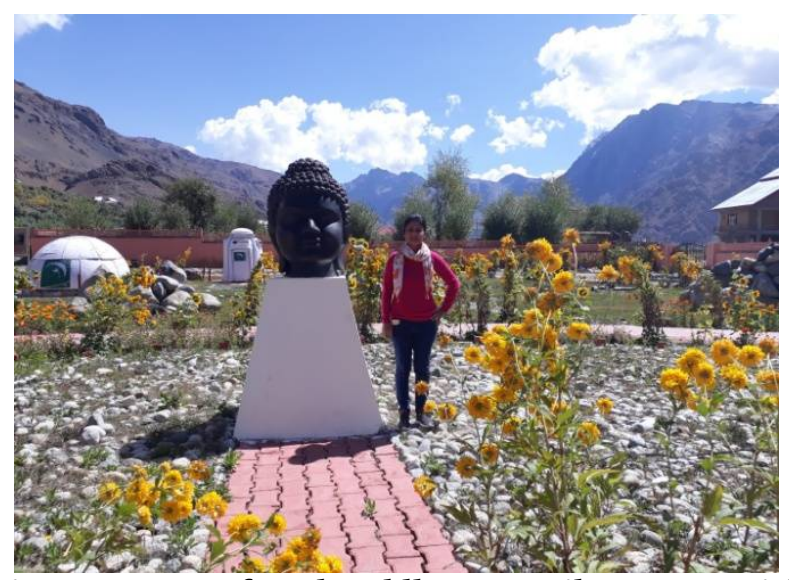

Picture 11, Bust of Lord Buddha at Kargil war memorial

The statue of Buddha in the middle of war memorial (Picture 11) along with display of war machinery (Picture 10) used at the time of Kargil war finds layers of meaning which are in juxtaposition with each other at the memorial site. On one hand, the place symbolizes extreme perils of war and sacrifice for the spirit of nationhood and on the other it injects a sense of calmness and enlightenment about the immortality of life through the statue head of Buddha. This memorialisation marks out the sacred space within the iconography of spiritual and lethal weaponry of war. The captured Pakistani bunkers in the background (Picture 11) also give a dualistic picture of a real space with different spaces juxtaposing.

The fifth principle of heterotopia which is evident at these war memorial sites states how "Heterotopias always presuppose a system of opening and closing that both isolates them and makes them penetrable" (Mirzoeff, 2002, p. 243). Foucault describes heterotopia as sites at which one is subject to rites and purifications and which are not necessarily freely accessible to the public. He is referring to sacred sites at which various religious and hygiene rules must be observed. To enter these places one must have certain permissions and make certain gestures. Something similar is true of museums. The rituals on special days of remembrance mean that they are marked by "systems of opening and closing" (Mirzoeff, 2002, p.243), special gestures are made at these sites. On certain days they are treated as sacred sites. Kargil Vijay Diwas is celebrated every year on 26 July in honour of the Kargil War's Heroes at Drass. 
Establishing the heterotopic nature of both the Kargil and Dhruva war memorial as subject to a system of opening and closing that isolates them and makes them penetrable, these sites are set apart physically. Kargil war memorial situated on route National Highway 1, exists on the edge of the city of Kargil. As part of his argument for the increasing rise of the non-place of supermodernity, Marc Augé in Non-Places: Introduction to an Anthropology of Supermodernity considers the way in which all places publicly announce their historical legacies to passing motorists through road signs and billboards. These are Augé calls "business cards" for the area, which make the historical context explicit (1995, p.68). They are aimed at motoring tourists encouraging them to pause awhile as if, he says, "alluding to former times and places were today just a manner of talking about present space" (Augé, 1995, p. 73-74). The existence of the memorial outside the town of Drass acts not just as a site of traditional historical narrative but of memory and consumption. The geography of Drass takes on a rather distinctive role in its exhibit. The artefacts and reconstruction all contribute to position the visitor as voyeur. Many visitors seemed to enjoy the simulation, finding pleasure in that in-betweenness, a pleasure that was only possible in terms of modern spectator positions. This pleasure is dispensed with the priority of the original over the copy, reality over the representation. Impressive models of the war terrain along with the video played on Kargil war are used to animate what Peter Mandler calls, extravagant dioramas representing historic events (1999, p.135). They involve as Kevin Hetherington says "spatial play" (1997, p.12) and contribute to Kargil Memorial being a heterotopic memory site. Kargil and Dhruva war memorial provides a clear example of the demands made on visitors (Picture 12). It is as an enclosed world that cannot be seen or heard unless one shows ones identity proof and registers ones particulars.

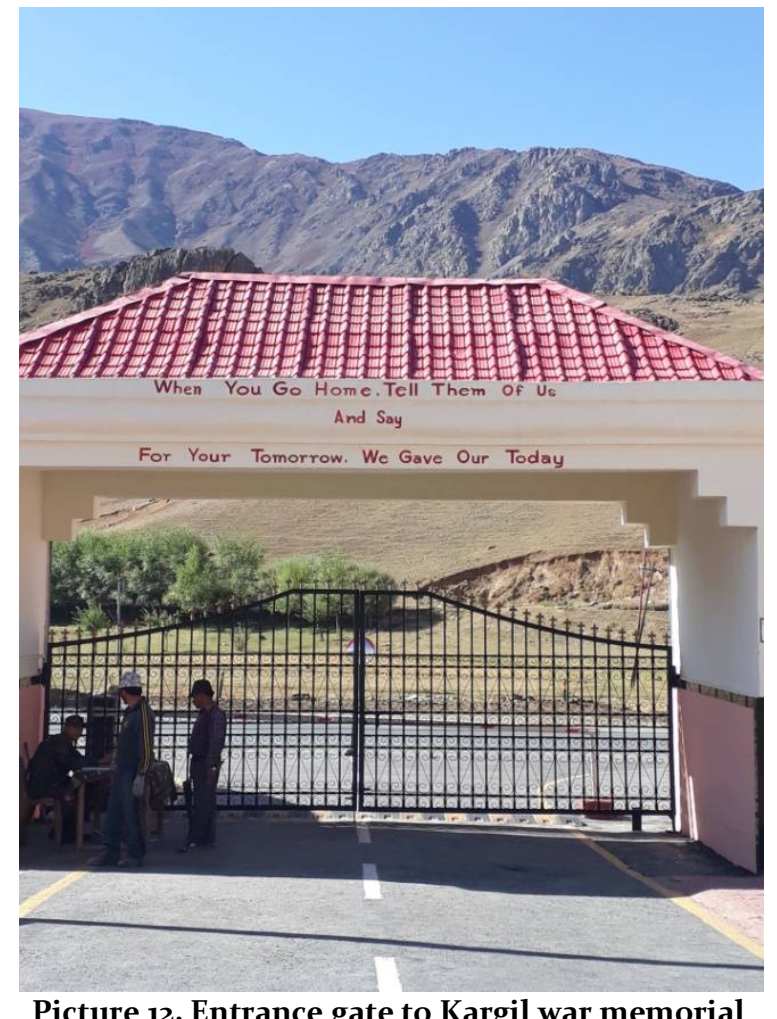

When Foucault states that heterotopias are not places to be entered freely, he was not referring to the price (in this case to prove ones identity) of admission but to rituals at the thresholds. Still, the 
act of proving ones identity is a formal requirement that heightens the experience of entering. It necessarily excludes and creates a barrier to pass. Having proven ones identity one enters into the world of war memorial. The memorial site then, encourages particular modes of conduct and behaviour within its walls. However, it also engenders ways of seeing which produce an understanding of the place of Jammu and Kashmir that exists beyond them.

\section{Conclusion}

War memorials and monuments are integral to the popular militarized expression of Jammu and Kashmir's territorial entity. These serve as performative public structures for the society to interact with them and bear witness to the commemorative act. The paper demonstrates how memorializing and cultural meanings ascribed to the spaces of war dead can be perceived as a complex combination of territorial, non territorial, embodied, collective and visceral. Its materialistic aesthetics is unpacked in conjunction with embodied actions, written texts and visual images. Thus, memory scapes can be understood only through the ways in which these spaces, nonspaces, are visualised, practised, performed and lived. The central arguments reside in the assertion that material dimensions of memory making are significant not just in the marking of soldier's death, but also in the social and cultural processes through which lives are remembered.

\section{Notes}

'This is Sarah Ahmed's term. In "Affective Economies" (Ahmed 2004c), she proposes the idea of 'economy of affect', urging us to see affect not as purely individual and psychic entity but as something that 'circulates' in society, among bodies. She shows how 'circulating' emotions 'align' some subject with others, but against others, marking the boundaries of the collective.

${ }^{i i}$ For Massumi, "Intensity is asocial, but not presocial [...] the trace of past actions including a trace of their contexts [are] conserved in the brain and in the flesh" (Massumi, Parables for the Virtual 30: original emphasis).

iii Foucault summarizes six principles of these 'different' spaces. In brief, they become established in all cultures but in diverse forms (especially as sites of 'crisis' or later 'deviation'), mutate and have specific operations at different points in history, juxtapose in a single space several incompatible spatial elements, encapsulate spatio- temporal discontinuities or intensities, presuppose an ambivalent system of opening/closing, entry/ exit, distance/penetration and have a specific operation in relation to other spaces as, for example, illusion or compensation.

\section{References}

Abousnnouga, Naiema. G. (2012). Visual and Written Discourses of British Commemorative War Monuments. [Unpublished Doctoral Dissertation].Cardiff University.

Ahmed, S. (2004a). The Cultural Politics of Emotion. Edinburgh University Press.

--. (2004b). Collective feelings: or, the impressions left by others. Theory, Culture and Society, vol.

21 (2), 25-42.

--. (2004C). Affective economies. Social Text, vol. 79 (2), 117-139. 
Auǵe, M. (1995). Non-Places: Introduction to an Anthropology of Supermodernity. (John Howe,Trans.). Verso.

Bavidge, E. (2009). Heterotopias of Memory: Cultural Memory in and around Newcastle upon Tyne.

[Doctoral Dissertation, University of Sunderland].University of Sunderland Repository. http://sure.sunderland.ac.uk/3558/.

Bondi, L., Davidson, J. and Smith, M. (2005). Introduction: Geography’s “Emotional Turn”. In J. Davidson, L. Bondi, and M. Smith (Eds.), Emotional Geographies. Ashgate Publishing.

Butler, J. (2010). Frames of War. Taylor and Francis.

Certeau de M. (2011). The Practice of Everyday Life. (Steven F. Rendall, Trans.). University of California Press.

Chambers, W and Robert. (1990).The Chambers English Dictionary. 7th edn. W \& R Chambers Ltd.

Clough, Patricia T. (2007). The Affective Turn: Theorizing the Social. Duke University Press.

Crampton, W. J and Elden, S. (2007). Space, Knowledge and Power: Foucault and Geography. Ashgate Publishing.

Debord, G. (2006). The Society of the Spectacle. (Donald Nicholson-Smith, Trans.). Zone.

Doss, E. (2008).The Emotional Life of Contemporary Public Memorials: Towards a Theory of Temporary Memorials. Amsterdam University Press. ISBN: 978908964 0185 ISSN: 1872-0986. --. (2010). Memorial Mania: Public Feeling in America. University of Chicago Press.

du Gay P, Hall S, Jones L, et al. (1997.) Doing cultural studies : the story of the Sony Walkman. Sage Publications.

Foucault, M. (1983a). The Subject in Power. Beyond Structuralism and Hermeneutics. University of Chicago Press.

--. (1984). Of Other Spaces: Utopias and Heterotopias. (Jay Miskowiec, Trans.), Architecture /Mouvement/ Continuité.

--. (1998). Of Other Spaces: Utopias and Heterotopias. In Nicholas Mirzoeff (Ed.),The Visual Culture Reader. Routledge.

--. (2002b). The Order of Things: An Archaeology of the Human Sciences. Routledge Classics.

Hallam, E. and Hockey, J. (2001). Death, Memory and Material Culture. Berg

Hetherington, K. (1997). The Badlands of Modernity: Heterotopia and Social Ordering. Routledge.

India TV News Desk Srinagar. (August 11, 2016). Goosebumps!Kargil War Hero Captain VijayantThapar's father climbs $16000 \mathrm{ft}$ to visit the place where his son achieved martyrdom. India TV. https://www.indiatvnews.com/news/india-kargil-war-hero-captain-vijayant-thapar-s-father-climbs1600o-ft-to-visit-the-place-where-his-son-achieved-martydom-343311.

Jones, A. (2007). Memory and Material Culture. Cambridge University Press.

The Hindu. (26 July 2009). Kargil martyrs remembered. The Hindu. https://www.thehindu.com/todays-paper/tp-national/Kargil-martyrsremembered/article16563253.ece

Lefebvre, H. (1991). The Production of Space. (Donald Nicholson-Smith, Trans.). Blackwell.

Lister, M. and Wells, L. (2000). Seeing Beyond Belief: Cultural Studies as an Approach to Analysing the Visual. In Leeuwen, van T. and Jewitt, C. (Eds.), The Handbook of Visual Analysis, Sage.

Maddrell, A. (2016). Mapping Grief.A Conceptual Framework for Understanding the Spatial Dimensions of Bereavement, Mourning and Remembrance. Social \& Cultural Geography, vol. 17 (2), 166-188, doi: 10.1080/14649365.2015.1075579.

Mandler, P. (1999). 'The Wand of Fancy': The Historical Imagination of the Victorian Tourist. In Marius Kwint, Christopher Breward and Jeremy Aynsley (Eds.), Material Memories. Berg. 
Massumi, B. (1987). Notes on the translation and acknowledgments. In G. Deleuze and F. Guattari (Eds.), A Thousand Plateaus: Capitalism and Schizophrenia. (B. Massumi Trans.), xvi-xix. University of Minnesota Press.

--. (1995). The Autonomy of Affect. Cultural Critique, vol.31, 83-109.

--. (2002). Parables for the Virtual: Movement Affect, Sensation. Duke University Press.

Mazzarella, W. (2009). Affect: What is it Good for? In Saurabh Dube (Ed.), Enchantments of Modernity Empire, Nation, Globalization. Routledge.

Mehrabani, Mohammad R and Khamseh, Ali A. (Spring 2016). War Memorial Landscape; From Realism to Metaphor. Warscape and City. NAZAR Research Center. 34 (8).

Merrifield, A. (2000). Henri lefebvre: A Socialist in Space. In M. Crang and N. Thrift (Eds.), Thinking Space. Routledge, $167-182$.

Mirzoeff, N. (Ed.). (1998).The Visual Culture Reader. Routledge.

--. (2002). The Subject of Visual Culture. In N. Mirzoeff (Ed.), The Visual Culture Reader. 2nd ed.

Routledge.

--. (2009). An Introduction to Visual Culture. Routledge

Mitchell, W.J.T. (1994). Imperial Landscape. In W.J.T Mitchell (Ed.), Landscape and Power. Chicago University Press.

--. (2005). What Do Pictures Want? : The Lives and Loves of Images. University of Chicago Press.

Morgan, M.J. (2001). Sites of Memory: Memorialisation in the Landscape. Dissertation. University of Canterbury.

Nayar, K. P. (2011). States of Sentiment: Exploring the Cultures of Emotion. Orient Black Swan.

Ochsner, J.K. (February 1997). A Space of Loss: The Vietnam Veterans Memorial. Journal of Architectural Education. Vol. 50(3):156171, doi: 10.1080/10464883.1997.10734719.

Osiel, M. (1997). Mass Atrocity, Collective Memory, and the Law. Transaction Publishers.

Pearson, M and Shanks, M. (2001). Theatre/ Archaeology. Routledge.

Saunders, J. N. (2004). Matters of Conflict: Material Culture, Memory and the First World War. Roultledge.

--. (2005). Culture, Conflict, and Materiality: The Social Lives of Great War Objects. In B. Finn and B.C. Hacker (Eds.), Materializing the Military. 77-94.

Tally, R. (2013). Spatiality. Routledge.

Till, K. (2005). The New Berlin: Memory, Politics, Place. University of Minnesota Press.

Wagner-Pacifici, R., Schwartz, B. (1991). The Vietnam Veterans' Memorial: Commemorating a Difficult Past. American Journal of Sociology, 97 (2), 376- 420.

Wilson, M. T. and Donnan H. (2016). A Companion to Border Studies. John Wiley and Sons.

Wright, C. (2013). The Presence of Absence and Other States of Space. [Doctoral Dissertation, Staffordshire University]. Staffordshire Online Repository. http://eprints.staffs.ac.uk/2201/1/Wright\%20C.\%20A.\%20PhD\%2oFine\%2oArt\%2oand\%2oPhilosop hy\%20July\%202013.pdf. 
Dr.Ritika Pathania received her doctoral degree from Department of English, Central University of Jammu, India. Her doctoral thesis proposes to explore the visual and cultural economy of War memorials situated in the erstwhile state of Jammu and Kashmir. She did her M. Phil in English Literature on the topic "Poetics and Politics of Representation of Kargil War". Her research publications include a book chapter in Visual Politics of War-Truth and Lies of Soft Power-Volume 2, edited by Ibrahim Saleh and Thomas Knieper and published by Cambridge Scholars Publishing. Her research interests include visual cultural studies, memory and affect, politics of space and the idea of nation.

Dr. Raj Thakur is currently an Assistant Professor in the Department of English, Central University of Jammu, Jammu, India. He received his doctoral degree from Department of English and Cultural Studies, Panjab University, Chandigarh with specific focus on "Cultural Economy of Leisure and Indian Premier League.” His research interests include cultural studies, popular culture, sports literature and visual culture. 